\title{
PROPERTIES OF HIGH-PERFORMANCE FIBER-REINFORCED CONCRETE AFTER THERMAL TREATMENT AT HIGH TEMPERATURES
}

\author{
LASTNOSTI VISOKOKAKOVOSTNEGA, Z VLAKNI OJAČANEGA \\ BETONA PO TOPLOTNI OBDELAVI PRI VISOKIH \\ TEMPERATURAH
}

\author{
Zbyšek Pavlík ${ }^{1}$, Jan Fořt ${ }^{1}$, Milena Pavlíková ${ }^{1}$, Lucie Zemanová ${ }^{1}$, \\ Jaroslav Pokorný ${ }^{1}$, Anton Trník ${ }^{1}$, David Cítek ${ }^{2}$, Robert Černý ${ }^{1}$ \\ ${ }^{1}$ Department of Materials Engineering and Chemistry, Faculty of Civil Engineering, Czech Technical University in Prague, Thákurova 7, \\ 16629 Prague, Czech Republic \\ ${ }^{2}$ Department of Experimental Methods, Klokner Institute, Czech Technical University in Prague, Šolínova 7, 16608 Prague, Czech Republic
}

Prejem rokopisa - received: 2018-03-20; sprejem za objavo - accepted for publication: 2019-01-17

doi:10.17222/mit.2018.050

A complex analysis of the effect of a high-temperature load on the parameters of a high-performance fiber-reinforced concrete (HPFRC) is presented. The HPFRC containing steel fibers was exposed to temperatures of up to $1000^{\circ} \mathrm{C}$. In order to reveal the effect of the elevated temperatures on the concrete performance, its basic physical, mechanical, hygric and thermal properties were determined after the thermal treatment. To observe physical and chemical processes in the HPFRC as a function of temperature, a simultaneous thermal analysis (STA) and a thermodilatometry analysis (TDA) were used. The high-temperature exposure led to an increase in the porosity and pore size and to a significant decrease in the mechanical strength. The values of hygric and thermal properties correspond to the changes in the material structure after the thermal treatment. STA and TDA data showed structural changes of the studied material and allowed identification of critical temperatures for its damage.

Keywords: fiber-reinforced concrete, high-temperature exposure, thermal strain, structural changes

Avtorji predstavljajo kompleksno analizo vpliva termičnih obremenitev na parametre visokokakovostnega, z vlakni ojačanega betona (HPFRC). Preiskovani beton, ki je vseboval jeklena vlakna, so izpostavili visokim temperaturam do $1000{ }^{\circ} \mathrm{C}$. Po toplotni obdelavi betona so ugotavljali vpliv visokih temperatur na njegove fizikalne, mehanske in hidro-termalne lastnosti. Fizikalne in kemijske procese HPFRC $\mathrm{v}$ odvisnosti od temperature so ugotavljali s pomočjo simultane termične analize (STA) in termodilatometrije (TDA). Termična obremenitev preiskovanega betona je povzročila povečanje velikosti por in posledično povečanje celokupne poroznosti ter znatno zmanjšanje njegove mehanske trdnosti. Vrednosti hidro-termalnih lastnosti po termični obremenitvi betona so se spremenile skladno s spremembami v strukturi materiala. Rezultati STA in TDA analiz kažejo na strukturne spremembe preiskovanega materiala in omogočajo identifikacijo kritičnih temperatur začetka njegovih poškodb.

Ključne besede: z jeklenimi vlakni ojačan beton, visoko temperaturna obremenitev, termične deformacije, strukturne spremembe

\section{INTRODUCTION}

High-performance fiber-reinforced concrete (HPFRC) became a popular and modern structural material for versatile use. Under conventional environmental conditions, concrete structures serve without any bigger durability problems, especially in the case of applying high-performance materials. ${ }^{1}$ However, there are important cases where these structures may be exposed to much higher temperatures (e.g., building fires and explosions, chemical and metallurgical industrial applications, and some nuclear-power-related postulated accident conditions). Here, a concrete exposure to high-temperature loading significantly reduces its excellent properties, such as compactness, mechanical resistance, durability, etc. $^{2}$

*Corresponding author's e-mail: pavlikz@fsv.cvut.cz
Fire represents one of the most severe risks to buildings and structures. The Channel Tunnel fires in 1996 and 2008, and the St Gotthard Tunnel fire in 2001 are typical examples of a serious HPC damage due to a high-temperature load. The fire-induced damage of HPC structures is associated with a release and evaporation of a significant amount of water. Due to this reason, internal stresses are built up in the concrete, which can exceed its tensile strength. Since HPC has a significantly finer pore structure compared to the normal-strength concrete (NSC), it is much more difficult for this internal pressure to be released. In both progressive spalling and explosive spalling, the load-bearing capacity of the concrete structure is reduced and a complete failure may ultimately occur. ${ }^{3}$ However, of the two previously assumed reasons, evaporation is nowadays believed to be only reason for internal stresses. The second reason is the gradient between the temperature of the heated external layers of a concrete element and its cooler inside where the latter 
hinders the expansion of the former and causes high stresses to evolve in the heated layer., ${ }^{4,5}$ This is why different spalling types and patterns are observed on concrete elements of different dimensions and shapes (e.g. concrete beams, columns, plates or walls; elements with a rectangular or circular cross-section, etc.) as well as on the same elements heated by different heating rates (faster heating regimes most often result in more aggressive spalling).

The surface of a concrete element can be heated by both a convective heat flux (from the surrounding air of a higher temperature) and a radiation heat flux (direct, e.g., from flames, and/or mutual, e.g., from other heated surfaces), resulting in a gradual increase of the element temperature, starting from the surface zone. Increasing temperature causes material dilatation, which is in part due to concrete dehydration (products of chemical reactions have a greater volume than the initial volume of concrete), in part due to the material cracking and progressive crack opening, ${ }^{6}$ and finally due to "normal" thermal dilatation of the material skeleton. A thermal dilatation of the external layers of a heated element is constrained by the core material, which has a lower temperature. This causes considerable macro-stresses in the external layers of the element, compression in the direction parallel to the surface, and traction in the direction perpendicular to it, as well as an accumulation of the elastic strain energy. The tensile stresses may cause further development of cracks and fractures, parallel to the element surface, resulting in a subsequent degradation of the material strength properties in the surface zone. $^{4}$

An intensive research was carried out to propose solutions that would provide active or passive protection against spalling. In order to minimize HPC spalling, different types of fibres based on steel, basalt, jute, polyvinyl alcohol (PVA), polypropylene (PP), polyacrylnitrile (PAN), etc., were tested separately or as a hybridfibre reinforcement, where combinations of different fibre materials and sizes were used.

Steel fiber reinforced concrete (SFRC) exhibits several excellent properties, such as flexural, tensile and shear strengths, toughness, impact resistance, crack resistance and resistance to frost damage. Although steel fibers may not offer any obvious advantage from the fire-endurance point of view, previous works have shown that steel fibers can affect the spreading of cracking, hence, potentially improving the performance of concrete after its exposure to high temperatures. ${ }^{7}$ Sideris et al. ${ }^{8}$ reported on steel-fiber-bridge cracks caused by an increased vapor pressure, which underwent a more gradual degradation. Lau and Anson ${ }^{7}$ found that incorporated steel fibers are beneficial to the concrete exposed to high temperatures of up to $1200{ }^{\circ} \mathrm{C}$. Additionally, the steel fibers may cause a short time delay of spalling due to the increase in the tensile strength of the cement matrix. However, the time of the spalling delay lies in the order of minutes. Nevertheless, the steel fibers can shift threshold temperatures to higher levels as introduced by Sideris et al. ${ }^{8}$ Since SFRC has already found application in the building industry, for example, in tunnel lining and precast tunnel segments, its behavior during high-temperature loading and its residual parameters are of particular importance. On this account, the HPFRC reinforced by steel fibers in an amount of $120 \mathrm{~kg} / \mathrm{m}^{3}$ was studied and the results are reported in this article.

\section{EXPERIMENTAL PART}

\subsection{Materials and specimens}

The HPFRC mix, developed in our laboratory with special attention paid to its high mechanical resistance and durability, was examined. The tested material consisted of Portland slag cement CEM II/A-S 42.5 R (the Č́́žkovice cement factory, Czech Republic, member of the LafargeHolcim group), silica sand with the maximum particle size of $2 \mathrm{~mm}$, mineral microfillers, steel fibers and batch water. Steel fibers MasterFiber 482 (BASF) with a tensile strength of $2200 \mathrm{MPa}$ were straight, $13 \mathrm{~mm}$ long, $0.2 \mathrm{~mm}$ thick (with an aspect ratio of 65) and brass coated (Figure 1).

The chosen thickness and length are proper for application in the HPC and UHPC where the aspect ratio in a range of $65-100$ is recommended. For the optimal workability of a fresh concrete mixture, a superplasticizer based on polycarboxylate ether was used. A detailed composition of the studied HPFRC is given in Table 1.

The specimens prepared were cubes with a side length of $100 \mathrm{~mm}$ and rectangular prisms having dimensions of $40 \mathrm{~mm} \times 40 \mathrm{~mm} \times 160 \mathrm{~mm}$. The cast samples were stored for $24 \mathrm{~h}$ in a highly humid environment of approximately $98 \% \mathrm{RH}$ and after demolding, they were cured for $27 \mathrm{~d}$ in water with a temperature of $(23 \pm 2){ }^{\circ} \mathrm{C}$. After this time, they were stored in the laboratory

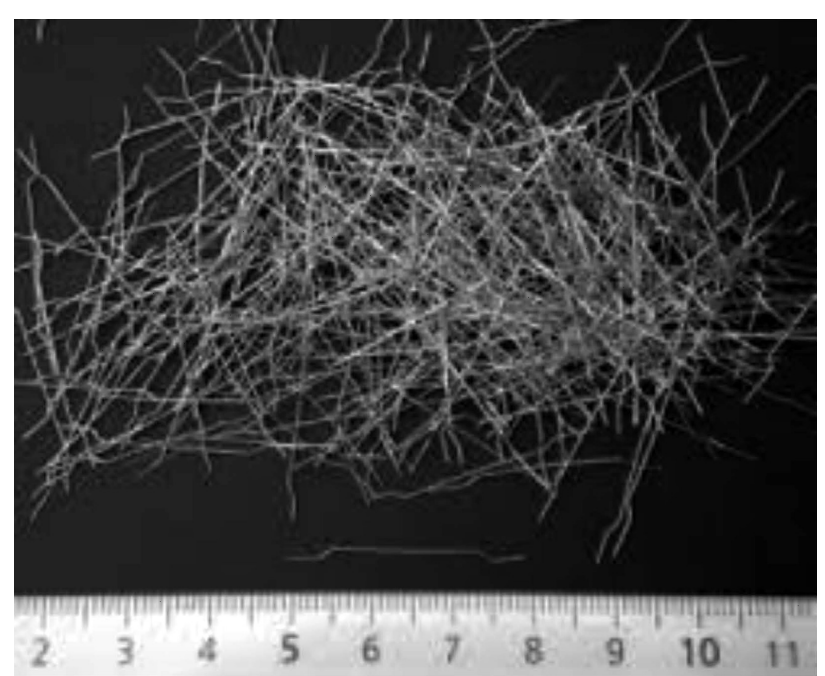

Figure 1: Steel fibers 
$\left(R H=(50 \pm 5) \%, T=(23 \pm 2){ }^{\circ} \mathrm{C}\right)$. The storage of specimens in a laboratory environment was necessary for their free drying to a low equilibrium moisture content in order to prevent their damage by the accelerated water evaporation. At the age of $120 \mathrm{~d}$, all of the HPFRC specimens were first dried at $105{ }^{\circ} \mathrm{C}$ until their mass was constant, i.e., the mass change was lower than $0.1 \%$ of the specimen mass. After this age, some of the prepared specimens were placed into an electrical furnace with a heating rate of $5 \mathrm{~K} / \mathrm{min}$. The maximum temperature was $(200,400,600,800$ and 1000$){ }^{\circ} \mathrm{C}$, respectively. The applied heating rate was in our case less than that of the ISO 834 standard curve, which was the limitation of the equipment available. The holding time at the maximum temperature was two hours. After two hours, the temperature of whole sample reached equilibrium (no temperature gradients occurred). Before the particular tests of HPFRC residual properties, the specimens were cooled down under laboratory conditions.

Table 1: HPFRC mix amounts

\begin{tabular}{|l|c|}
\hline \multicolumn{1}{|c|}{ Material } & Dosage $\left(\mathrm{kg} / \mathrm{m}^{3}\right)$ \\
\hline Silica sand 0.18-2 mm & 824 \\
\hline Silica sand 0.063-1 mm & 411 \\
\hline Master Fiber 482 (BASF) $0.2 / 13 \mathrm{~mm}$ & 120 \\
\hline CEM II 42.5 R & 690 \\
\hline Silica fume & 100 \\
\hline Slag & 80 \\
\hline Superplasticizer & 40 \\
\hline Water & 160 \\
\hline
\end{tabular}

\subsection{Measurement methods}

The experimental testing of the HPFRC properties included determination of the pore-size distribution, basic physical, mechanical, hygric and thermal properties. For each test, three parallel samples were used.

Among the basic physical properties, bulk density, matrix density and total open porosity were measured. The bulk density $\rho_{\mathrm{b}}\left(\mathrm{kg} / \mathrm{m}^{3}\right)$ of the cubic specimens was determined using the standard gravimetric principle according to EN 12390-7.9 The specimen volume was obtained by measuring the specimen length and weighing its dry mass. The expanded combined uncertainty of the bulk density was $2.4 \%$. The matrix density $\rho_{\text {mat }}$ $\left(\mathrm{kg} / \mathrm{m}^{3}\right)$ was obtained with a Pycnomatic ATC helium pycnometer (Thermo Scientific). Using the measurement results from the bulk-density and matrix-density tests, the total open porosity $\phi(\%)$ was calculated. ${ }^{10}$ The expanded combined uncertainty of the total open porosity was $3 \%$.

The effect of high temperatures on the porous structure of the studied HPFRC specimens was examined using mercury intrusion porosimetry (MIP). For the measurement, a combination of Pascal 140 and Pascal 440 (Thermo Scientific) porosimeters was used. These apparatuses are able to identify the pores having diameters in ranges of $116-3.8 \mu \mathrm{m}$ and $15-0.0036 \mu \mathrm{m}$, respectively. The sample mass was about $1-2 \mathrm{~g}$, depending on the rate of material damage and porosity increase. The samples were taken from the inner part of the cubic specimens used for testing residual thermal properties. For each elevated temperature, three parallel samples were tested to ensure the reproducibility of our results.

The mechanical properties including flexural strength, compressive strength and dynamic Young's modulus were measured. The flexural strength $f_{f}(\mathrm{MPa})$ was determined using the three-point-bending test arrangement described in standard EN 1015-11. ${ }^{11}$ The span length between supports was $100 \mathrm{~mm}$. The compressive strength $f_{c}(\mathrm{MPa})$ was measured in accordance with the same standard using the fragments of the specimens from the flexural-strength tests. The loading area was $40 \mathrm{~mm} \times 40 \mathrm{~mm}$. The expanded combined uncertainty of both strength tests was $1.4 \%$. The dynamic Young's modulus $E(\mathrm{GPa})$ was measured with a DIO 562 pulse ultrasonic device (Starmans Electronics) with a frequency of $50 \mathrm{kHz}$.

Based on the water-sorptivity concept, the water absorption coefficient $A\left(\mathrm{~kg} /\left(\mathrm{m}^{2} \cdot \mathrm{s}^{1 / 2}\right)\right)$ was measured following EN 1015-18. ${ }^{12}$ From the measured water absorption coefficient and saturated moisture content value $w_{\text {sat }}\left(\mathrm{kg} / \mathrm{m}^{3}\right)$ of the analyzed material, the apparent moisture diffusivity $\kappa\left(\mathrm{m}^{2} / \mathrm{s}\right)$ was calculated.

The water vapor transmission has a clear effect on the evaporation during the concrete heating. The associated material properties were measured using the cup method in a dry-cup arrangement of the test, i.e., the cup contained silica gel and was placed in a controlled climatic chamber where a constant relative humidity of $50 \%$ and constant temperature of $21{ }^{\circ} \mathrm{C}$ were maintained. The water vapor diffusion permeability $\delta(\mathrm{s})$, the water vapor diffusion coefficient $D\left(\mathrm{~m}^{2} / \mathrm{s}\right)$ and the water vapor resistance factor $\mu(-)$ were determined using the procedure introduced by Fořt et al. ${ }^{13}$

An ISOMET 2114 transient-impulse device (Applied Precision) was used for the measurement of heat transport and storage properties including thermal conductivity $\lambda(\mathrm{W} /(\mathrm{m} \cdot \mathrm{K}))$, thermal diffusivity $a\left(\mathrm{~m}^{2} / \mathrm{s}\right)$ and volumetric heat capacity $c_{\mathrm{v}}\left(\mathrm{J} /\left(\mathrm{m}^{3} \cdot \mathrm{K}\right)\right)$ at room temperature.

For the characterization of the chemical and physical processes in the HPFRC during its exposure to high temperatures, a simultaneous thermal analysis (STA) and thermodilatometry (TDA) were applied. The STA was performed using a Labsys Evo apparatus (Setaram) in a temperature range of $25-1200{ }^{\circ} \mathrm{C}$, with a heating rate of $5 \mathrm{~K} / \mathrm{min}$. The measurement was done in an argon atmosphere with a flow rate of $40 \mathrm{ml} / \mathrm{min}$. The powdered samples with a mass of about $50 \mathrm{mg}$ and without any fibers were placed in an alumina crucible with a lid. The length changes of the studied material induced by a high-temperature load were measured using a horizontal thermodilatometer produced by Clasic CZ, Ltd. Rectangular prisms with dimensions of $20 \mathrm{~mm} \times 20 \mathrm{~mm} \times$ 
$160 \mathrm{~mm}$ were used as specimens. The measurement was done in a static air atmosphere in a temperature interval from $25{ }^{\circ} \mathrm{C}$ to $1000{ }^{\circ} \mathrm{C}$. The applied heating rate was 1 $\mathrm{K} / \mathrm{min}$ to minimize any thermal gradients in the heated specimens. From the measured temperature-induced length changes, the linear thermal expansion coefficient was obtained. The STA and TDA experiments were repeated three times to ensure the reproducibility of our results.

\section{RESULTS AND DISCUSSION}

The values for the matrix and bulk density and porosity of the studied HPFRC are given in Table 2 . The HPFRC was found to have a low porosity and a dense internal structure. From the quantitative point of view, the porosity values measured for the reference samples and samples exposed to a heating temperature of $200{ }^{\circ} \mathrm{C}$ are almost similar, corresponding to the porosity values measured, e.g., by Yu et al. ${ }^{14}$ The temperature exposure starting at $400{ }^{\circ} \mathrm{C}$ yielded a higher porosity and a decrease in the bulk density, clearly demonstrating the decay effect of a thermal treatment on the concrete structure.

Table 2: Bulk and matrix density and porosity of HPFRC at room temperature

\begin{tabular}{|c|c|c|c|}
\hline $\begin{array}{c}\text { Maximum load } \\
\text { temperature }\end{array}$ & $\rho_{\mathrm{b}}\left(\mathrm{kg} / \mathrm{m}^{3}\right)$ & $\rho_{\text {mat }}\left(\mathrm{kg} / \mathrm{m}^{3}\right)$ & $\phi(\%)$ \\
\hline Reference & 2363 & 2561 & 7.8 \\
\hline $200{ }^{\circ} \mathrm{C}$ & 2349 & 2554 & 8.0 \\
\hline $400{ }^{\circ} \mathrm{C}$ & 2260 & 2666 & 15.2 \\
\hline $600{ }^{\circ} \mathrm{C}$ & 2250 & 2670 & 15.7 \\
\hline $800{ }^{\circ} \mathrm{C}$ & 2220 & 2930 & 24.2 \\
\hline $1000^{\circ} \mathrm{C}$ & 2110 & 2920 & 27.7 \\
\hline
\end{tabular}

The coarsening of the pore structure due to the chemical and physical decomposition of the HPFRC examined with the MIP analysis is depicted in Figure 2. For the reference specimen and the specimens exposed to the temperature of $200{ }^{\circ} \mathrm{C}$, the maximum pore diameter is about $10 \mu \mathrm{m}$, whereas most of the pores have a size

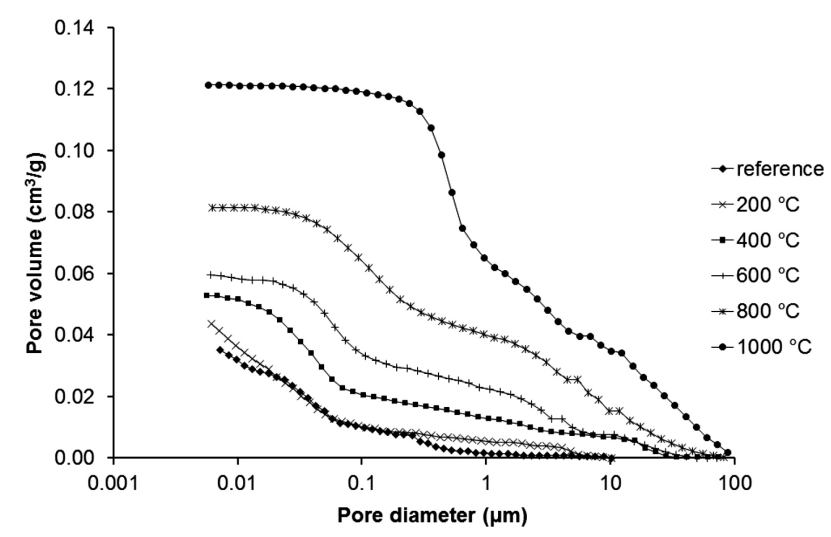

Figure 2: Cumulative pore-size distribution between $0.01 \mu \mathrm{m}$ and $0.50 \mu \mathrm{m}$. This means that the amount of large capillary pores (classification according to Taylor ${ }^{15}$ ) having a negative effect on the strength of the material and water permeability is limited, yielding a low porosity and a high mechanical resistance. On the other hand, the MIP data clearly revealed the influence of a high-temperature load on the pore structure of the concrete. With the increasing maximum temperature of the material, the pore volume and the pore size systematically grew, clearly supporting the relevance of the obtained material parameters listed above.

The mechanical properties of the studied concrete specimens are summarized in Table 3 .

Table 3: Residual and reference mechanical properties (flexural strength $f_{\mathrm{f}}$, compressive strength $f_{\mathrm{c}}$, and Young's modulus $E$ ) of HPFRC measured at room temperature

\begin{tabular}{|c|c|c|c|}
\hline $\begin{array}{c}\text { Maximum load } \\
\text { temperature }\end{array}$ & $f_{\mathrm{f}}(\mathrm{MPa})$ & $f_{\mathrm{c}}(\mathrm{MPa})$ & $E(\mathrm{GPa})$ \\
\hline Reference & 31.9 & 170.3 & 52.1 \\
\hline $200^{\circ} \mathrm{C}$ & 31.0 & 168.9 & 47.9 \\
\hline $400^{\circ} \mathrm{C}$ & 23.4 & 128.4 & 31.5 \\
\hline $600^{\circ} \mathrm{C}$ & 19.1 & 118.1 & 15.4 \\
\hline $800^{\circ} \mathrm{C}$ & 10.5 & 64.4 & 9.6 \\
\hline $1000^{\circ} \mathrm{C}$ & 1.3 & 16.1 & 4.6 \\
\hline
\end{tabular}

It can be seen that the influence of thermal treatment on the mechanical properties of the tested HPFRC can be divided into three main stages. The mechanical properties of the specimens exposed to the maximum temperature of $200{ }^{\circ} \mathrm{C}$ are more or less comparable to the properties of the reference specimen. Due to the thermal treatment at temperatures in the interval from $400{ }^{\circ} \mathrm{C}$ to $800{ }^{\circ} \mathrm{C}$, the mechanical properties dramatically decrease and at temperatures above $800{ }^{\circ} \mathrm{C}$, most of the mechanical strength is lost. The measured mechanical properties are comparable to the data published, e.g., by Ma et al. ${ }^{16}$ who observed similar retained mechanical properties after high-temperature tests.

The structural changes that the HPFRC underwent at high temperatures are clearly indicated by the STA results given in Figure 3. In the temperature interval from $25^{\circ} \mathrm{C}$ to $300{ }^{\circ} \mathrm{C}$, the liberation of physically bound water from the pores and the dehydration reaction of $\mathrm{C}-\mathrm{S}-\mathrm{H}$ phases took place. Additionally, AFt and AFm phases dehydrated at $110-156{ }^{\circ} \mathrm{C}$ as described by Liu at al. ${ }^{17}$ The endothermic peak at $445{ }^{\circ} \mathrm{C}$ corresponds to the Portlandite decomposition. ${ }^{15}$ The next relevant temperature for the studied material is $572{ }^{\circ} \mathrm{C}$ when the transformation of the quartz aggregate took place. ${ }^{18}$ This reaction is accompanied by a sharp endothermic heat-flow peak and a volume expansion. There is no change of mass during the quartz transformation as seen from the TG curve. In the temperature interval from $560{ }^{\circ} \mathrm{C}$ to $850{ }^{\circ} \mathrm{C}$, the calcite and C-S-H phases' decomposition occurred. The carbonation of $\mathrm{C}-\mathrm{S}-\mathrm{H}$ leads to the formation of vaterite, which seems to be an unstable type of calcium carbonate. ${ }^{16}$ The temperature range of the corresponding 


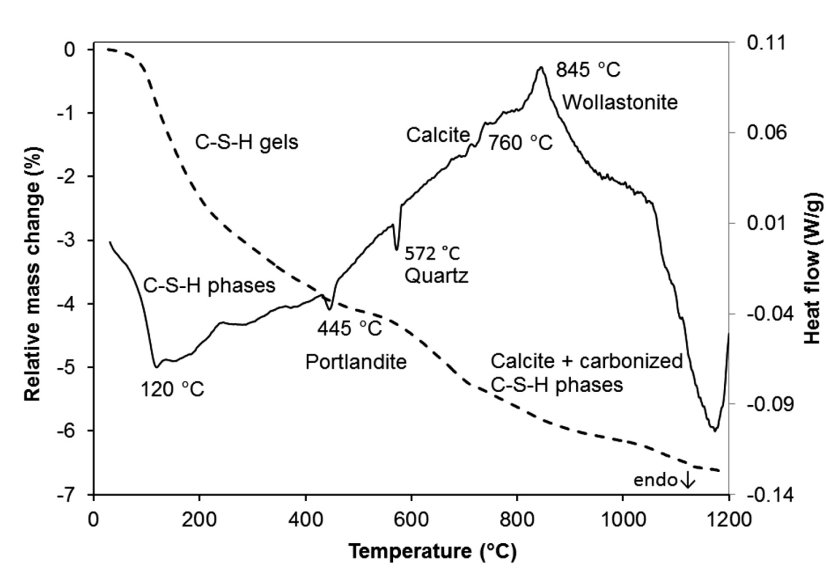

Figure 3: DSC and TG curves of the studied HPFRC

decompositions is difficult to determine because the peaks overlap. The significant exothermal peak corresponds to the crystallization of wollastonite. ${ }^{19}$

TDA data is shown in Figure 4. The thermal-strain data clearly refers to the material-length changes due to the linear heating of up to $1000{ }^{\circ} \mathrm{C}$ and indicates several structural changes. Looking at the linear thermal expansion coefficient plotted as a function of temperature, at a temperature of about $445^{\circ} \mathrm{C}$, one can observe the effect of the decomposition of portlandite and at a temperature of $572{ }^{\circ} \mathrm{C}$, the transformation of $\alpha \rightarrow \beta$ quartz that both led to a significant thermal expansion. Another distinct expansion was observed in the temperature interval from about $790{ }^{\circ} \mathrm{C}$ to $900{ }^{\circ} \mathrm{C}$. Here, the length changes were induced by the decomposition of calcite, carbonized calcium silicate hydrates and crystallization of wollastonite as recorded during the STA. In the temperature interval from $590{ }^{\circ} \mathrm{C}$ to about $680{ }^{\circ} \mathrm{C}$, no significant expansion was observed and the studied material even underwent a limited thermal shrinkage. This was a result of the strain incompatibilities between the cement paste and the aggregates. While the aggregates and mineral fillers dilate with the increasing temperature until they are chemically degraded, the cement paste shrinks as soon as it loses water due to drying and dehydration. Apparently, in this temperature interval the rate of the aggregate's chemical degradation was lower compared to the shrinkage of the concrete matrix. The shrinkage recorded in the temperature interval from about $720{ }^{\circ} \mathrm{C}$ to $758{ }^{\circ} \mathrm{C}$ was found by Estevez ${ }^{20}$ and can be assigned to the formation of a new silica compound.

The thermal properties of the investigated HPFRC specimens are given in Table 4. This data corresponds to the measured porosity values and characterizes the material behavior from the point of view of heat transport and storage after the exposure to elevated temperatures. In the literature, the thermal and hygric properties of the HPC are studied rarely. Vejmelková et al. ${ }^{21}$ investigated the thermal and hygric properties of the HPC with metakaoline. For the HPC, they obtained a porosity of $13.0 \%$, a thermal conductivity of about $1.8 \mathrm{~W} /(\mathrm{mK})$ and

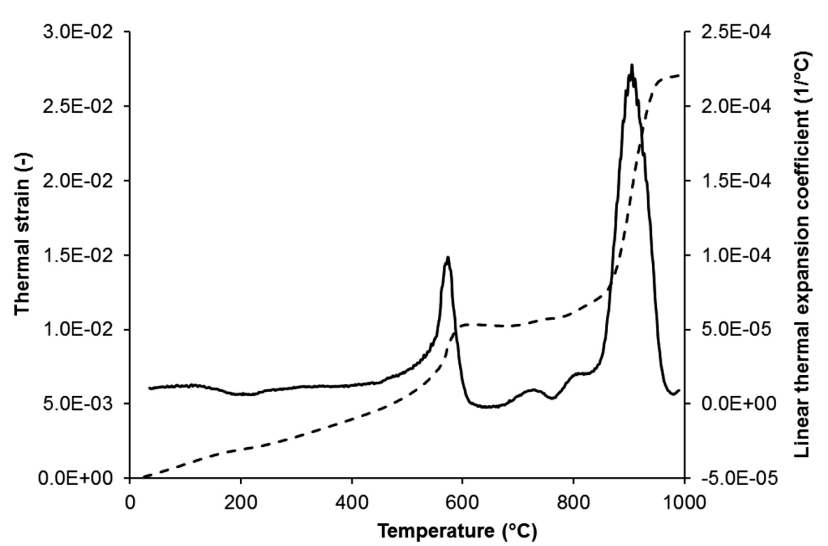

Figure 4: Thermal strain and linear thermal expansion coefficient of the studied HPFRC

a thermal diffusivity of about $1.04 \times 10^{-6} \mathrm{~m}^{2} / \mathrm{s}$. We obtained similar values for our specimens exposed to $400{ }^{\circ} \mathrm{C}$, having a porosity of $15.2 \%$. It is obvious that a high-temperature load leads to a deceleration of heat transport and thus to a slower water evaporation from the hydrated concrete structure. This phenomenon is favorable for possible evaporation of free water and water of hydrated products because a dense HPC structure prevents free water from escaping, causing a considerable internal vapor pressure, which often results in spalling. In this way, the high-temperature-induced changes of a pore structure retard partially the concrete damage. Additionally, the higher porosity of high-temperatureexposed specimens allows the evaporation of water from concrete hydrates. This leads to a lower internal vapor pressure compared to undamaged concrete.

Table 4: Thermal properties (thermal conductivity $\lambda$, volumetric heat capacity $c_{\mathrm{V}}$ and thermal diffusivity $a$ ) of HPFRC measured at room temperature

\begin{tabular}{|c|c|c|c|}
\hline $\begin{array}{c}\text { Maximum load } \\
\text { temperature }\end{array}$ & $\begin{array}{c}\lambda \\
(\mathrm{W} /(\mathrm{m} \cdot \mathrm{K}))\end{array}$ & $\begin{array}{c}c_{\mathrm{V}} \\
\left(\times 10^{6} \mathrm{~J} /\left(\mathrm{m}^{3} \cdot \mathrm{K}\right)\right)\end{array}$ & $\begin{array}{c}a \\
\left(\times 10^{-6} \mathrm{~m}^{2} / \mathrm{s}\right)\end{array}$ \\
\hline Reference & 2.20 & 1.72 & 1.27 \\
\hline $200^{\circ} \mathrm{C}$ & 2.17 & 1.71 & 1.26 \\
\hline $400^{\circ} \mathrm{C}$ & 1.70 & 1.69 & 1.01 \\
\hline $600^{\circ} \mathrm{C}$ & 1.41 & 1.63 & 0.87 \\
\hline $800^{\circ} \mathrm{C}$ & 1.22 & 1.56 & 0.78 \\
\hline $1000^{\circ} \mathrm{C}$ & 1.06 & 1.40 & 0.76 \\
\hline
\end{tabular}

The hygric properties of the studied HPFRC specimens are summarized in Table 5.

Table 5: Hygric properties of HPFRC tested at room temperature

\begin{tabular}{|c|c|c|c|c|c|}
\hline $\begin{array}{c}\text { Maximum } \\
\text { load tem- } \\
\text { perature }\end{array}$ & $\begin{array}{c}A(\mathrm{~kg} / \\
\left.\left(\mathrm{m}^{2} \cdot \mathrm{s}^{1 / 2}\right)\right)\end{array}$ & $\kappa\left(\mathrm{m}^{2} / \mathrm{s}\right)$ & $\delta(\mathrm{s})$ & $D\left(\mathrm{~m}^{2} / \mathrm{s}\right)$ & $(-)$ \\
\hline Reference & 0.0001 & $1.72 \times 10^{-11}$ & $6.1 \times 10^{-12}$ & $8.3 \times 10^{-7}$ & 27.7 \\
\hline $200^{\circ} \mathrm{C}$ & 0.0003 & $1.84 \times 10^{-11}$ & $7.4 \times 10^{-12}$ & $1.0 \times 10^{-6}$ & 22.7 \\
\hline $400{ }^{\circ} \mathrm{C}$ & 0.0306 & $5.93 \times 10^{-8}$ & $1.1 \times 10^{-11}$ & $1.5 \times 10^{-6}$ & 15.0 \\
\hline $600{ }^{\circ} \mathrm{C}$ & 0.0803 & $3.06 \times 10^{-7}$ & $1.4 \times 10^{-11}$ & $1.9 \times 10^{-6}$ & 12.0 \\
\hline $800^{\circ} \mathrm{C}$ & 0.1491 & $5.67 \times 10^{-7}$ & $1.8 \times 10^{-11}$ & $2.4 \times 10^{-6}$ & 9.4 \\
\hline $1000{ }^{\circ} \mathrm{C}$ & 0.2124 & $9.45 \times 10^{-7}$ & $2.4 \times 10^{-11}$ & $3.3 \times 10^{-6}$ & 7.1 \\
\hline
\end{tabular}



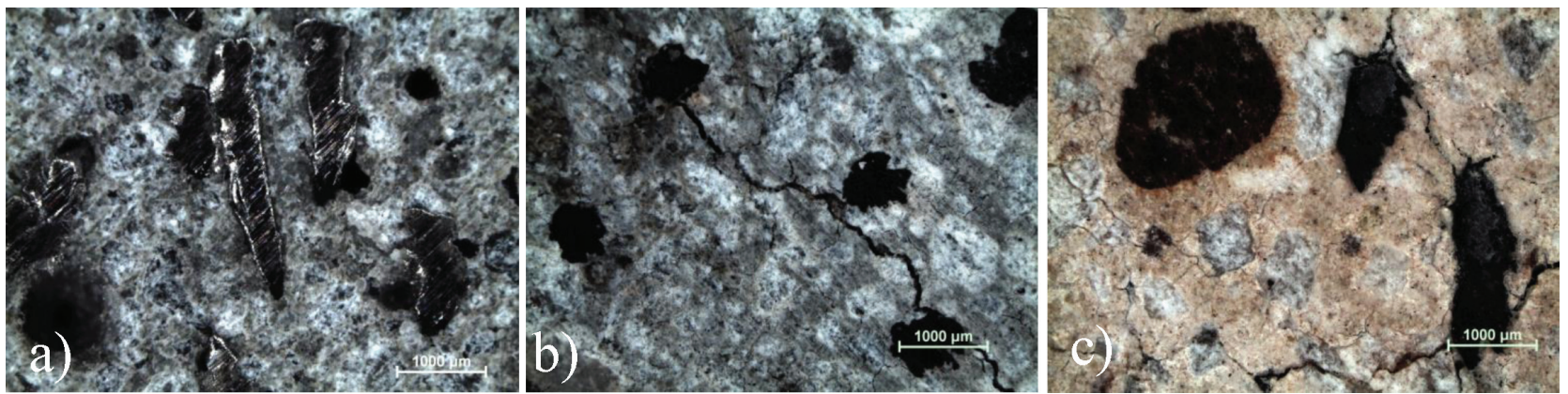

Figure 5: Optical-microscopy images of HPFRC: a) reference sample, b) sample exposed to $600{ }^{\circ} \mathrm{C}$, c) sample exposed to $1000{ }^{\circ} \mathrm{C}$

For both, the reference specimen and the specimen exposed to $200{ }^{\circ} \mathrm{C}$, the liquid water-transport properties were almost undetectable. With the increasing load temperature, all the studied hygric properties increased due to the structural changes described above. From the practical point of view, the increase of the pore volume and changes in the pore-size distribution accelerate the water evaporation. This is partially in conflict with the above stated effect of the increased porosity with a higher temperature load and thus certain retardation of concrete overheating. Nevertheless, the deceleration of the overheating of the concrete is only limited because the thermal-conductivity values are high for all the studied specimens. In the case of underground tunnel linings and other structures exposed to excessive moisture, an opening of the concrete pore structure and thus an increase in the water ingress into the material can induce or/and accelerate its damage.

In order to support the data above and visualize the damage of the HPFRC, optical microscopy was used to identify the crack formation and steel-fiber deterioration. The used optics consisted of an objective revolver (0.58-7×, Navitar), lens attachment $2 \times$ and a color 3.15 Mpx CMOS sensor camera (ProgRes CT3). In Figure 5, optical scans of the reference specimen and specimens exposed to $600{ }^{\circ} \mathrm{C}$ and $1000{ }^{\circ} \mathrm{C}$ are shown. One can observe significant changes in the material structure followed by color changes, steel-fiber damage and cracks formed due to the joined thermo-hygric-mechanical effects described above.

\section{CONCLUSIONS}

The experimental analyses and tests made in this work revealed significant structural changes in the studied HPFRC at temperatures higher than $200{ }^{\circ} \mathrm{C}$. Such a complex analysis of the changes in the material parameters of hybrid-fiber-reinforced high-performance cement-based composites subjected to high temperatures has not been presented yet and will contribute to an increase in the level of scientific knowledge in the studied field. An increase of the total open porosity and pore size due to the exposure to elevated temperatures led to a significant reduction of the mechanical strength.
The changes in the properties of the investigated HPFRC were explained with STA and TDA data that allowed an identification of the transformation and decomposition of hydrated products in the HPC matrix.

A unique complete set of thermal and hygric properties of the HPFRC as a function of thermal treatment represents valuable information for practical use of the HPFRC. It can be applied as in-put data for the modelling of concrete damage and coupled mechanical and hygrothermal performance at a high-temperature exposure. As many numerical models have been developed, ${ }^{22,23}$ attempting to simulate and predict the spalling phenomenon for specific concrete mixes, structural forms and fire-loading scenarios, various material parameters are applied as input data for a numerical analysis of concrete damage at high temperatures. For example, Gawin at al. ${ }^{4}$ presented a fully generalized, coupled, multi-phase, hygro-thermo-mechanical model for heated concrete where the dehydration degree obtained from the TG data, porosity, density, mechanical properties, effective thermal conductivity, specific heat capacity and thermal-strain values obtained with this research can find use. Similarly, Zhang et al. ${ }^{24}$ applied, in their model of concrete spalling, other parameters including water-saturation degree, thermal-expansion coefficient, thermal conductivity, specific heat capacity, mechanical parameters, water-vapor diffusion coefficient, etc. The obtained hygric and thermal properties of the tested HPFRC can find use also in the design of engineering structures and buildings. Based on a literature analysis, we can say that this data is of a particular importance for future research focused on the development of the HPFRC resistant to elevated temperatures. Our future research activities will comprise design and complex testing of a new advanced type of HPFRC with hybrid fiber reinforcement, while the experimental tests will be aimed at both the residual properties after a temperature load and the concrete properties measured directly at high temperatures.

\section{Acknowledgment}

The authors greatly acknowledge the financial support of the Czech Science Foundation within project 


\section{Z. PAVLÍK et al.: PROPERTIES OF HIGH-PERFORMANCE FIBER-REINFORCED CONCRETE ...}

P105/12/G059 and of the CTU in Prague within project No SGS17/166/OHK1/3T/11.

\section{REFERENCES}

${ }^{1}$ A. Dufka, T. Melichar, J. Bydžovský, J. Vaněrek, The development of new types of secondary protection for concrete structures exposed to extreme conditions, Mater. Technol., 51 (2017), 533-540, doi:10.17222/mit.2015.249

${ }^{2}$ A. Caverzan, M. Colombo, M. di Prisco, B. Rivolta, High performance steel fibre reinforced concrete: residual behaviour at high temperature, Mater. Struct., 48 (2015), 3317-3329, doi:10.1617/ s11527-014-0401-9

${ }^{3}$ M. Beneš, R. Štefan, Hygro-thermo-mechanical analysis of spalling in concrete walls at high temperatures as a moving boundary problem, Int. J. Heat Mass Transf., 85 (2015), 110-134, doi:10.1016/j.ijheatmasstransfer.2015.01.050

${ }^{4}$ D. Gawin, F. Pesavento, B. A. Schrefler, Towards prediction of the thermal spalling risk though a multi-phase porous media model of concrete, Comput. Methods Appl. Mech. Eng., 195 (2006), 5707-5729, doi:10.1016/j.cma.2005.10.021

${ }^{5}$ J. Jansson, Fire Spalling of Concrete: Theoretical and Experimental Studies, PhD Thesis, KTH Royal Institute of Technology, Division of Concrete Structures, Stockholm 2013

${ }^{6}$ U. Schneider, Concrete at high temperatures - A general review, Fire Safety J., 13 (1988), 55-68, doi:10.1016/0379-7112(88)90033-1

${ }^{7}$ A. Lau, M. Anson, Effect of high temperatures on high performance steel fibre reinforced concrete, Cement Concrete Res., 36 (2006), 1698-1707, doi:10.1016/j.cemconres.2006.03.024

${ }^{8}$ K. K. Sideris, P. Manita, E. Chaniotakis, Performance of thermally damaged fibre reinforced concretes, Constr. Build. Mater., 23 (2009), 1232-1239, doi:10.1016/j.conbuildmat.2008.08.009

${ }^{9}$ EN 12390-7:2000 Testing hardened concrete - Part 7: Density of hardened concrete, CEN, Brussel

${ }^{10}$ M. Záleská, M. Pavlíková, Z. Pavlík, O. Jankovský, J. Pokorný, V. Tydlitát, P. Svora, R. Černý, Physical and chemical characterization of technogenic pozzolans for the application in blended cements, Constr. Build. Mater., 160 (2018), 106-116, doi:10.1016/j.conbuildmat.2017.11.021

${ }^{11}$ EN 1015-11:1999 Methods of test for mortar for masonry - Part 11: Determination of flexural and compressive strength of hardened mortar, CEN, Brussel
${ }^{12}$ EN 1015-18:2002 Methods of test for mortar for masonry - Part 18: Determination of water-absorption coefficient due to capillary action of hardened mortar, CEN, Brussel

${ }^{13}$ J. Fořt, Z. Pavlík, J. Žumár, M. Pavlíková, R. Černý, Effect of temperature on water vapor transport properties, J. Build. Phys., 38 (2014), 156-169, doi:10.1177/1744259114532612

${ }^{14}$ R. Yu, P. Spiesz, H. J. H. Brouwers, Mix design and properties assessment of ultra-high performance fibre reinforced concrete, Cement Concrete Res., 56 (2014), 29-39, doi:10.1016/j.cemconres. 2013.11.002

${ }^{15}$ H. F. W. Taylor, Cement Chemistry, $2^{\text {nd }}$ ed., Thomas Telford, London 1997

${ }^{16}$ Q. Ma, R. Guo, Z. Zhao, Z. Lin, K. He, Mechanical properties of concrete at high temperature - A review, Constr. Build. Mater., 93 (2015), 371-383, doi:10.1016/j.conbuildmat.2015.05.131

${ }^{17}$ S. Liu, L. Wang, Y. Gao, B. Yu, Y. Bai, Comparing study on hydration properties of various cementitious systems, J. Therm. Anal. Calorimetry, 118 (2014), 1483-1492, doi:10.1007/s10973-0144052-4

${ }^{18}$ P. J. Heaney, D. R. Veblen, Observations of the $\alpha-\beta$ phase transition in quartz: A review of imaging and diffraction studies and some new results, Am. Mineralogist, 76 (1991), 1018-1032

${ }^{19}$ A. Yazdani, H. R. Rezaie, H. Ghassai, Investigation of. hydrothermal synthesis of wollastonite using silica and nano silica at different pressures, J. Ceram. Process. Res., 11 (2010), 348-353

${ }^{20}$ L. P. Estevez, On the hydration of water-entrained cement-silica systems: Combined SEM, XRD and thermal analysis in cement pastes, Thermochim. Acta, 518 (2011), 27-35, doi:10.1016/j.tca.2011. 02.003

${ }^{21}$ E. Vejmelková, M. Pavlíková, M. Keppert, Z. Keršner, P. Rovnaníková, M. Ondrářek, M. Sedlmajer, R. Černý, High performance concrete with Czech metakaolin: Experimental analysis of strength, toughness and durability characteristics, Constr. Build. Mater., 24 (2010), 1404-1411, doi:10.1016/j.conbuildmat.2010.01.017

${ }^{22}$ C. Davie, C. H. J. Pearce, N. Bićanić, A fully generalised, coupled, multi-phase, hygro-thermo-mechanical model for concrete, Mater. Struct., 43 (2010), 13-33, doi:10.1617/s11527-010-9591-y

${ }^{23}$ D. Ružić, J. Kolšek, I. Planinc, M. Saje, T. Hozjan, Non-linear fire analysis of restrained curved RC beams, Eng. Struct., 84 (2015), 130-139, doi:10.1016/j.engstruct.2014.11.012

${ }^{24}$ Y. Zhang, M. Zeiml, Ch. Pichler, R. Lackner, Model-based risk assessment of concrete spalling in tunnel linings under fire loading, Eng. Struct., 24 (2014), 207-215, doi:10.1016/j.engstruct.2014. 02.033 